\title{
IbM PENGELOLAAN KEUANGAN SEDERHANA UNTUK USAHA KECIL PADA KELOMPOK TANI NELAYAN "KAMINTONG" DI DESA ERIS KECAMATAN ERIS KABUPATEN MINAHASA PROVINSI SULAWESI UTARA
}

\author{
Stanny Sicilia Rawung \\ Program Studi Pendidikan Ekonomi, Fakultas Ekonomi, Universitas Negeri Manado \\ stannyrawung@unima.ac.id
}

\begin{abstract}
ABSTRAK
Kelompok Tani Nelayan Kamintong adalah salah satu kelompok tani nelayan yang terdapat di Desa Eris Kecamatan Eris. Kelompok tani ini terdiri dari 10 orang anggota, dimana para anggota tersebut merupakan para pemilik usaha kecil dalam bidang budi daya ikan air tawar. Ikan air tawar yang di hasilkan pada umumnya dipasarkan di wilayah kabupaten Minahasa dan Propinsi Sulawesi Utara pada umumnya. Fluktuasi harga yang terjadi secara nasional juga berdampak pada para ang gota kelompok tani nelayan dalam hal pemenuhan kebutuhan mereka akan pakan ikan dan kebutuhan usaha lainnya. Hal tersebut mendorong para anggota kelompok menyediakan modal lebih banyak untuk menutupi kebutuhan mereka, kurangnya modal akan mengakibatkan penurunan produksi ikan air tawar. Salah satu cara untuk pemenuhan modal usaha adalah dengan mengambil kredit di bank, namun pada saat pengusulan kredit di bank, kadang para anggota kelompok tidak mendapatkan fasilitas kredit tersebut karena mereka tidak dapat memenuhi salah satu persyaratan kredit bank yaitu pencatatan keuangan usaha (proses akuntansi usaha). Dengan latar belakang pendidikan yang beragam, membuat para anggota kelompok memiliki pemahaman yang tidak sama dalam hal pencatatan keuangan usaha. Dari latar belakang permasalahan pengelolaan keuangan Mitra, maka salah satu solusi yang akan dilakukan dalam Program IBM ini adalah pelatihan pencatatan keuangan usaha kecil dengan menggunakan akuntansi sederhana. Metode yang diterapkan adalah klasikal dan individual. Metode pendekatan ini dalam bentuk ceramah dan praktek. Pendekatan indivudual dilakukan pada saat praktek berupa pencatatan transaksi sampai pada penyusunan laporan keuangan.
\end{abstract}

Kata kunci : usaha kecil, akuntansi, ikan air tawar,kelompok tani nelayan, pendekatan klasikal, pendekatan individual

\section{PENDAHULUAN}

\section{Analisis Situasi}

Usaha kecil dan Menengah (UKM) berperan cukup besar dalam menunjang kestabilan perekonomian Indonesia, terutama setelah kridid ekonomi melanda. Sejak terjadinya krisis ekonomi di tahun 1998, UKM mulai bermunculan di pelosok-pelosok nusantara. Usaha kecil dapat bertahan di tengah krisis Karena di dukung oleh modal usaha yang berasal dari modal pribadi.

Usaha kecil di Indonesia memegang peranan penting dalam perkembangan perekonomian di Indonesia. Hal ini dapat terlihat dari bukti nyata bahwa sebagian besar usaha kecil di Indonesia tidak terpengaruh krisis global yang terjadi akhir- akhir ini. 
Meskipun jumlah usaha kecil terus berkembang, namun kondisi di lapangan menunjukkan beberapa keterbatasan usaha kecil. Diantaranya, perkembangan jumlah usaha kecil dari tahun ke tahun terus meningkat dari sisi kuantitas saja. Dari aspek finansial, hanya sedikit usaha kecil yang mengalami perkembangan kinerja keuangannya. Hal ini disebabkan karena kurangnya pemahaman dari pelaku usaha kecil terhadap pentingnya pengelolaan keuangan. Pengelolaan keuangan menjadi bagian penting bagi kemajuan usaha.

Pengelolaan keuangan dapat dilakukan melalui akuntansi. Akuntansi merupakan proses sistematis untuk menghasilkan informasi keuangan yang dapat digunakan untuk pengambilan keputusan bagi penggunanya. Akuntansi akan memberikan beberapa manfaat bagi pelaku usaha kecil, antara lain: (1) dapat mengetahui kinerja keuangan perusahaan, (2) dapat mengetahui dan membedakan harta perusahaan dan harta pemilik, (3) dapat mengetahui posisi dana baik sumber maupun penggunaannya, (4) dapat membuat anggaran yang tepat, (5) dapat menghitung pajak, dan (6) dapat mengetahui aliran uang tunai selama periode tertentu.

Melihat manfaat yang dihasilkan akuntansi, pelaku usaha kecil seharusnya sadar bahwa akuntansi sangat penting bagi usaha mereka. Namun, masih banyak usaha kecil yang belum menggunakan akuntansi dalam menunjang kegiatan bisnisnya. Alasan pelaku usaha kecil tidak menggunakan akuntansi antara lain adalah akuntansi dianggap sesuatu yang sulit dan tidak penting.

Beberapa pelaku usaha kecil mengatakan bahwa tanpa akuntansi pun usaha tetap berjalan lancar dan selalu memperoleh laba. Banyak pelaku usaha kecil merasa bahwa usaha mereka berjalan normal namun sebenarnya usaha kecil tersebut tidak mengalami perkembangan. Ketika mereka mendapatkan pertanyaan mengenai laba yang didapatkan setiap periode, mereka tidak bisa menunjukkan dengan nominal angka melainkan dengan aset berujud seperti tanah, rumah, atau kendaraan. Padahal aset tersebut didapatkan tidak hanya dengan dana perusahaan tetapi terkadang ditambah dengan harta pribadi. Aset tersebut terkadang juga bukan digunakan untuk perusahaan namun digunakan untuk kepentingan pribadi dan tidak terdapat pencatatan ataupun pemisahan di antara keduanya. Hal ini menyebabkan perkembangan usaha khususnya dalam hal kinerja keuangan tidak dapat diketahui secara jelas. Pelaku usaha kecil merasa kesulitan jika harus menggunakan akuntansi dalam kegiatan usahanya. Hal ini 
dikarenakan tidak adanya pedoman atau buku yang dapat dijadikan referensi untuk belajar mengelola keuangan usaha kecil. Buku- buku yang beredar saat ini memang belum ada yang fokus pada pengelolaan keuangan usaha kecil. Terdapat beberapa judul buku akuntansi untuk usah kecil, namun melihat isinya sama seperti buku akuntansi untuk perusahaan besar. Banyak transaksi yang terjadi di usaha kecil seperti barter/ tukar jasa namun tidak diberikan contoh dalam buku sehingga ketika transaksi tersebut terjadi, pelaku usaha kecil lebih memilih untuk tidak mencatatnya. Apabila terdapat banyak transaksi serupa dan tidak dicatat tentunya akan membawa dampak negatif bagi kinerja keuangan. Selain belum ada buku yang secara spesifik membahas transaksi dalam usaha kecil, banyak pelaku usaha kecil yang enggan membaca buku.

Keadaan yang dijelaskan diatas terjadi pada kelompok tani nelayan Kamintong, yang kegiatan utama mereka adalah usaha budidaya ikan air tawar di Danau Tondano, Fluktuasi harga yang terjadi secara nasional juga berdampak pada para anggota kelompok tani nelayan dalam hal pemenuhan kebutuhan mereka akan pakan ikan dan kebutuhan usaha lainnya. Hal tersebut mendorong para anggota kelompok menyediakan modal lebih banyak untuk menutupi kebutuhan mereka, kurangnya modal akan mengakibatkan penurunan produksi ikan air tawar. Salah satu cara untuk pemenuhan modal usaha adalah dengan mengambil kredit di bank, namun pada saat pengusulan kredit di bank, kadang para anggota kelompok tidak mendapatkan fasilitas kredit tersebut karena mereka tidak dapat memenuhi salah satu persyaratan kredit bank yaitu pencatatan keuangan usaha.(proses akuntansi usaha). Dengan latar belakang pendidikan yang beragam, membuat para anggota kelompok memiliki pemahaman yang tidak sama dalam hal pencatatan keuangan usaha.

Berdasarkan permasalahan tersebut, perlu diadakan kegiatan pelatihan bagi pelaku usaha kecil dalam hal mengelola keuangan dengan menggunakan akuntansi. Program pelatihan yang ditawarkan berupa pelatihan akuntansi sederhana bagi usaha kecil. Akuntansi yang diajarkan akuntansi bagi usaha kecil.Metode ini diharapkan akan mudah diserap, dan dalam penyampaiannya lebih mudah serta dapat dilakukan dalam waktu yang singkat

\section{Permasalahan}

Berdasarkan hasil survei, pengamatan dan diskusi dengan kelompok tani nelayan Kamintong di Desa Eris yang telah di rangkum dalam analisis situasi, maka dirumuskan permasalahan mitra sebagai berikut 
Perkembangan usaha belum sgignifikan, kinerja keuangan masih buruk dan ketidak mampuan sumber daya manusia dalam menggunakan akuntansi. Dari berbagai masalah tersebut, yang menjadi masalah utama adalah ketidak mampuan sumber daya manusia atau pelaku usaha kecil untuk menggunakan akuntansi dalam kaitannya dengan pengelolaan dana yang mereka miliki.

\section{METODE PELAKSANAAN}

Metode dan solusi yang di tawarkan

Alternatif pemecahan masalah dalam permasalahan mitra dilakukan pendampingan dengan dua pendekatan, yakni pendekatan klasikal dan individual. Pendekatan klasikal dilakukan pada saat penyampaian materi teknik penyusunan laporan keuangan sederhana. Pendekatan individual dilakukan pada saat praktek, yaitu simulasi penyusunan laporan keuangan. Untuk itu, metode yang akan dilakukan adalah:

1) Ceramah

Peserta diberikan motivasi agar memiliki kemauan untuk menggunakan akuntansi dalam kegiatan bisnisnya. Selain itu, peserta diberikan materi gambaran umum tentang akuntansi usaha kecil dan peran penting.

2) Praktek
Peserta pelatihan diberikan kesempatan untuk mendiskusikan permasalahan yang berkaitan dengan keuangan usaha kecil yang selama ini dihadapi. Selanjutnya peserta melakukan simulasi menyusun laporan keuangan mulai dari pencatatan transaksi sampai dengan menyusun laporan keuangan.

Partisipasi Mitra dalam Pelaksanaan Program

Dalam program ini untuk hal-hal yang bersifat prinsip akan dilakukan pendekatan konsultatif terhadap mitra. Mitra akan diminta pendapat-pendapatnya serta akan diberitahu atau diluruskan pendapat yang keliru atau menyimpang. Selanjutnya akan dilakukan pendekatan partisipatif, dimana bersama mitra membahas tentang

permasalahan, mencari alternatif pemecahan masalah, kemudian akan membuat keputusan secara bersama- sama.

\section{HASIL DAN PEMBAHASAN}

\section{Pengelolaan Keuangan Sederhana Untuk} Usaha Kecil

Ada beberapa pengertian mengenai pembukuan/akuntansi yaitu: akuntansi adalah 
seni pencatatan, penggolongan, peringkasan dan pelaporan transaksi-transaksi keuangan suatu organisasi dengan cara tertentu yang sistematis, serta penafsiran terhadap hasilnya. Objek kegiatan akuntansi adalah transaksi-transaksi keuangan, yaitu peristiwa-peristiwa atau kejadian-kejadian yang setidak-tidaknya bersifat keuangan misalnya penerimaan uang, pengeluaran uang, pembelian, penjualan yang bertujuan untuk memperoleh keuntungan. Proses akuntansi dapat digambarkan sebagai berikut

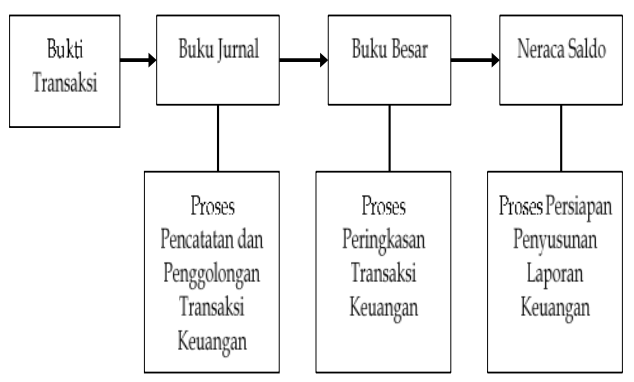

Gambar 1. Proses Akuntansi

\section{PERSAMAAN DASAR AKUNTANSI}

Perusahaan (perseorangan/perseroan) sebagai unit usaha yang berdiri sendiri, mempunyai kekayaan yang dapat diperoleh dari dua sumber, yaitu:

1. sumber kekayaan yang berasal dari pemilik.2. sumber kekayaan yang berasal dari pihak lain di luar pemilik (kreditur).
Kekayaan dalam istilah akuntansi dikenal dengan sebutan “AKTIVA”, sedangkan sumber kekayaan perusahaan yang berasal dari pemilikdisebut dengan istilah "MODAL". Istilah "UTANG" digunakan untuk menyebutkan sumber kekayaan perusahaan yang berasal dari kreditur. Modal dan Utang merupakan sumber aktiva perusahaan. Pembedaan istilah modal dan utang, dimaksudkan untuk menunjukkan perbedaan kewajiban perusahaan kepada pihak pemilik dan kepada pihak di luar pemilik.

Hubungan antara kekayaan yang berupa aktiva dengan sumber kekayaan yang berupa modal dan utang, dapat dinyatakan dengan persamaan dasar akuntansi sebagai berik

Asset $=$ Utang + Modal:

\section{Dasar Pencatatan}

Ada dua dasar pencatatan yang dapat dipergunakan dalam akuntansi yaitu:

1. Cash Basis

Pencatatan transaksi keuangan dilakukan pada saat transaksi keuangan yang bersangkutan telah diselesaikan secara tunai.

2. Accrual Basis

Pencatatan transaksi keuangan dilakukan pada saat terjadinya transaksi yang bersangkutan, terlepas apakah transaksi tersebut telah diselesaikan secara tnai atau belum. 


\section{REKENING}

Rekening merupakan alat yang dipergunakan dalam proses akuntansi yang berisi informasi mengenai saldo Aktiva, Utang, Modal, Pendapatan, dan Biaya. Setiap rekening diberi nama sesuai dengan nama pos-pos dalam laporan keuangan. Tidak ada ketentuan yang mengatur pemberian nama rekening. Rekening digunakan dalam penyusunan laporan keuangan suatu perusahaan.

Rekening-rekening tersebut adalah sebagai berikut:

\section{AKTIVA}

Merupakan sumber ekonomis perusahaan yang dinyatakan dengan satuan uang.

Aktiva dalam neraca dikelompokkan menjadi:

a. Aktiva Lancar

Aktiva perusahaan yang berupa kas atau aktiva lain yang diharapkan dapat dicairkan menjadi kas, dijual atau dipakai habis dalam satu tahun atau dalam siklus kegiatan normal perusahaan, jika melampaui stu tahun. Termasuk dalam aktiva lancar adalah:

- Kas dan Bank : Kas adalah alat pembayaran yang siap dan bebas digunakan untuk membiayai kegiatan umum perusahaan, yaitu berupa: uang, valuta asing, dan bentukbentuk alat pembayaran lainnya yang mempunyai sifat seperti kas. Bank adalah saldo simpanan perusahaan di bank berupa rekening giro, yang dapat digunakan secara bebas untuk membiayai kegiatan umum perusahaan.

- Piutang : Adalah hak untuk menerima pembayaran sejumlah tertentu dari pihak yang berkewajiban membayar pada saat tertentu.

- Persediaan Adalah barang-barang berwujud yang dimiliki oleh perusahaan dengan maksud untuk:

- Dijual (barang dagangan dan barang jadi)

- Masih dalam proses pengolahan untuk diselesaikan, kemudian

Dijual (barang dalam proses)

- Akan dipakai untuk meproduksi barang jadi yang akan dijual (bahan baku dan bahan pembantu)

b. Aktiva Tetap Berwujud

Aktiva berwujud yang diperoleh dalam bentuk siap pakai atau dengan dibangun lebih dahulu. Kriterianya:

- Dimiliki oleh perusahaan (hak milik)

- Digunakan dalam operasi perusahaan

- Tidak dimaksudkan untuk dijual dalam rangka kegiatan normal perusahaan

- Mempunyai masa manfaat (kegunaan) lebih dari satu tahun Yang termasuk dalam aktiva tetap berwujud seperti tanah, gedung, kendaraan, mesin, peralatan. 
c. Aktiva Tetap Tidak Berwujud

Merupakan hak-hak istimewa atau posisi yang menguntungkan perusahaan dalam menghasilkan pendapatan. Termasuk dalam kelompok ini antara lain: hak paten, hak cipta, franchise, merek dagang, goodwill.

\section{UTANG}

Utang (kewajiban) merupakan pengorbanan ekonomis yang wajib dilakukan oleh perusahaan pada masa yang akan datang, dalam bentuk penyerahan aktiva atau pemberian jasa, yang disebabkan oleh transaksi pada masa sebelumnya. Yang termasuk dalam utang adalah:

- Utang Dagang (Utang Usaha) Adalah utang yang timbul karena pemerolehan persediaan atau penerimaan jasa dalam rangka kegiatan normal (utama) perusahaan.

- Utang Biaya Adalah biaya-biaya yang masih harus dibayar karena perusahaan telah menikmati barang atau jasa tersebut, misalnya: utang gaji, utang bunga, biaya sewa yang masih dibayar, utang pajak dan sebagainya.

- Utang Pendapatan Adalah pendapatan dari penjualan barang atau jasa yang diterima di muka, sebelum penyerahan barang atau jasa, misalnya: uang muka penjualan, pendapatan jasa yang diterima dimuka, pendapatan komisi yang diterima dimuka.
- Utang Bank Adalah utang perusahaan kepada bank yang jangka waktu pelunasannya kurang dari satu eriode akuntansi.

\section{MODAL}

Adalah bagian hak pemilik dalam perusahaan yaitu selisih antara kativa dan utang yang ada. Modal perusahaan umumnya berasal dari investasi pemilik dan hasil usaha yang tidak dibagikan kepada pemilik perusahaan. Berkurangnya modal perusahaan, umumnya disebabkan oleh penarikan kembali penyertaan oleh pemilik, pembagian dividen, dan adanya kerugian.

\section{PENDAPATAN}

Pendapatan adalah peningkatan jumlah aktiva atau penurunan kewajiban perusahan yang timbul dari penyerahan barang/jasa atau kegiatan usaha yang lain di dalam satu periode akuntansi. Pendapatan yang berasal dari penyerahan barang dagangan atau pendapatan yang berasal dari penyerahan barang hasil produksi umumnya menggunakan istilah penjualan. Pendapatan dikelompokkan menjadi:

1). Pendapatan Usaha : Pendapatan yang diperoleh dari hasil usaha pokok perusahaan, misalnya penjualan barang dagangan atau barang hasil produksi.

2). Pendapatan Di Luar Usaha :Pendapatan yang diperoleh dari hasil di lar usaha pokok 
perusahaan, misalnya pendapatan bunga, pendapatan sewa.

\section{BIAYA}

Biaya adalah pengorbanan ekonomis yang diperlukan untuk memperoleh barang/jasa. Pengorbanan ekonomis tersebut dapat berupa pengurangan aktiva atau bertambahnya utang dan modal perusahaan. Biaya dikelompokkan menjadi:

1). Biaya yang dapat dihubungkan langsung dengan pendapatan yaitu Biaya yang secara langsung telah dimanfaatkan untuk memperoleh pendapatan dalam satu periode, misalnya harga pokok penjualan (HPP).

Pada umumnya para anggota kelompok tani nelayan yang merupakan pengusaha kecil usaha budi daya ikan air tawar menggunakan metode pencatatan akuntansi secara cash basis, dimana pada metode tersebut, pencatatan transaksi dilakukan apabila ada terjadi pengeluaran atau pendapatan dalam bentuk kas atau tunai
Tabel 1. Rekening yang ada pada usaha budidaya ikan air tawar

\begin{tabular}{|l|l|}
\hline No & Nama Rekening \\
\hline 1. & Kas \\
\hline 2. & Persediaan \\
\hline 3. & Peralatan \\
\hline 4. & Penjualan \\
\hline 5. & Biaya listrik \\
\hline 6. & Biaya transportasi \\
\hline 7. & $\begin{array}{l}\text { Biaya gaji dan upah tenaga } \\
\text { kerja }\end{array}$ \\
\hline
\end{tabular}

Tabel 2. contoh penggunaan biaya pada usaha budi daya perikanan air tawar

\begin{tabular}{|l|l|l|}
\hline NO & \multicolumn{1}{|c|}{ KOMPO NEN BIAYA } & SATUAN \\
\hline 1 & Biaya langsung & \\
\hline & Pembelian barang & \\
\hline & $\begin{array}{l}\text { Bibit Ikan Nila Hitam untuk 150 } \\
\text { jaring }\end{array}$ & ekor \\
\hline & Pakan ikan (pelet) $8893 \mathrm{ml}$ & sak \\
\hline & Pakan ikan (pelet) $8892 \mathrm{ml}$ & sak \\
\hline & Tenaga kerja & orang \\
\hline & Pengangkutan & unit \\
\hline 2 & Biaya Tidak Langsung & \\
\hline & Beban gaji dan upah & orang \\
\hline & Beban promosi & unit \\
\hline & Beban Listrik & unit \\
\hline & Beban umum dan lain-lain & unit \\
\hline
\end{tabular}


Tabel 3. Contoh Inventaris pada usaha budi daya perikanan air tawar

\begin{tabular}{|c|l|c|}
\hline No. & \multicolumn{1}{|c|}{ Jenis Inventaris } & Satuan \\
\hline 1 & $\begin{array}{l}\text { Jaring Pembesaran Ikan Nila } \\
\text { Hitam }\end{array}$ & Unit \\
\hline 2 & Jaring Pembibitan Ikan & Unit \\
\hline 3 & Jaring Penyortiran Ikan & Unit \\
\hline 4 & Jaring Ikan Hias & Unit \\
\hline 5 & Jaring Ikan Nila Merah & Unit \\
\hline 6 & Pompa Air 1 Set & Unit \\
\hline 7 & Tabung Oksigen & Unit \\
\hline 8 & Aquarium & Unit \\
\hline 9 & $\begin{array}{l}\text { Jaring Pembesaran Ikan Nila } \\
\text { Hitam }\end{array}$ & Unit \\
\hline 10 & Jaring Pembibitan Ikan & Unit \\
\hline
\end{tabular}

Table 4. Contoh Jurnal Umum Usaha Budi Daya Ikan Air Tawar

\begin{tabular}{|c|c|c|c|c|}
\hline \multicolumn{5}{|c|}{ JURNAL UMUM USAHA BUDI DAYA IKAN AIR TAWAR } \\
\hline NO & TGL/BLN & DESCRIPTION & DEBET & KREDIT \\
\hline 1 & 2-Jul & PENJUALAN & & $\mathrm{xxx}$ \\
\hline & & KAS & $\mathrm{xxx}$ & \\
\hline & & & & \\
\hline 2 & 2-Jul & BAYAR LISTRIK & $x x x$ & \\
\hline & & KAS & & $x \mathrm{xx}$ \\
\hline & & & & \\
\hline 3 & 2-Jul & BIAYA PROMOSI & $x x x$ & \\
\hline & & BIAYA TRANSPORTASI & $\mathrm{xxx}$ & \\
\hline & & KAS & & $\mathrm{xxx}$ \\
\hline & & & & \\
\hline 4 & 12-Jul & PENJUALAN & & $x \mathrm{xx}$ \\
\hline & & KAS & $x x x$ & \\
\hline & & & & \\
\hline 5 & 14-Jul & PERSEDIAAN & $\mathrm{xxx}$ & \\
\hline & & KAS & & $x x x$ \\
\hline & & & & \\
\hline 6 & 15-Jul & PENJUALAN & & $x x x$ \\
\hline & & KAS & $\mathrm{xxx}$ & \\
\hline & & & & \\
\hline 7 & 21-Jul & PERALATAN & $x x x$ & \\
\hline & & KAS & & $\mathrm{xxx}$ \\
\hline & & & & \\
\hline 8 & 31-Jul & BIAYA GAJI DAN UPAH TENAGA & $\mathrm{xxx}$ & \\
\hline & & KAS & & $x x x$ \\
\hline & & & & \\
\hline & & JUMLAH & - & - \\
\hline
\end{tabular}

Table 5. Contoh Laporan Laba/Rugi

\begin{tabular}{|c|c|c|c|}
\hline \multicolumn{4}{|c|}{ LABA RUGI } \\
\hline \multicolumn{4}{|c|}{ Untuk tahun yang berakhir pada 31 Desember 2015} \\
\hline $\mathrm{NO}$ & URAIAN & & \\
\hline & PENJUALAN & & $\operatorname{Rp} 2,422,065,000$ \\
\hline & PAKAN IKAN & Rp 1,791,965,000 & \\
\hline & TENAGA KERJA & Rp $\quad 57,600,000$ & \\
\hline & TRANSPORT/ANGKUTAN & \begin{tabular}{|ll}
$\mathrm{Rp}$ & $31,250,000$ \\
\end{tabular} & \\
\hline & KANTONG PLASTIK DAN OKSIGEN & $4,650,000$ & \\
\hline & HARGA POKOK PENJUALAN & & Rp $1,885,465,000$ \\
\hline & LABA KOTOR & & Rp $536,600,000$ \\
\hline & BIAYA-BIAYA & & \\
\hline & GAJI/UPAH KARYAWAN & Rp $24,000,000$ & \\
\hline & PROMOSI & \begin{tabular}{|ll}
$\mathrm{Rp}$ & $8,975,000$ \\
\end{tabular} & \\
\hline & LISTRIK & $6,200,000$ & \\
\hline & PERBAIKAN JARING & \begin{tabular}{|ll}
$\mathrm{Rp}$ & $76,375,000$ \\
\end{tabular} & \\
\hline & PENYUSUTAN & 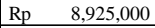 & \\
\hline & TOTAL BIAYA & & $\begin{array}{ll}\operatorname{Rp} & 124,475,000 \\
\end{array}$ \\
\hline & LABA & & 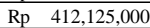 \\
\hline
\end{tabular}

\section{PEMBAHASAN}

Berdasarkan hasil pengamatan dan hasil evaluasi atas pelaksanaan kegiatan pelatihan terhadap khalayak sasaran atau peserta yakni para Anggota Kelompok Tani Nelayan Kamintong , diperoleh beberapa hasil pokok, antara lain bahwa peserta memiliki keinganan kuat untuk memperoleh baik secara teotitis maupun secara praktek hal-hal yang berhubungan dengan manajemen keuangan dan administrasi keuangan. Oleh karena itu antusiasme para khalayak sasaran sangat tinggi baik mengikuti maupun melaksanakan praktek penyusunan laporan keuangan.

Antusiasme para peserta pelatihan sangat tinggi karena dari hasil evaluasi ternyata para khalayak banyak yang belum mengetahui cara-cara penyusunan laporan keuangan. Ini 
ditunjukkan oleh banyak diantara peserta berupaya menyusun dengan bantuan dan bimbingan penyaji dan pembimbing praktek dan setiap saat ingin bertanya tentang cara-cara yang baik dalam manajemen keuangan maupun dalam pembuatan laporan keuangan.

\section{KESIMPULAN DAN SARAN}

\section{Kesimpulan}

Mengacu pada permasalahan dan pelaksanaan kegiatan bagi Para Anggota Kelompok Tani Nelayan Budidaya Kamintong, maka beberapa hal yang dapat disimpulkan adalah sebagai berikut :

1.Pelaksanaan kegiatan pelatihan berlangsung sangat responstif, dengan dukungan penuh para peserta. Dukungan peserta ditandai dengan aktifnya mereka mengikuti kegiatan dari awal sampai akhir kegiatan setiap hari, serta terlibat langsung secara aktif menanggapi setiap materi yang dianggap kurang paham. Demikian juga dengan praktek penyusunan kegiatan-kegiatan yang disarankan dibuat sesuai dengan format dan program yang dianjurkan.

2.Analisis keuangan dianggap materi yang paling penting bagi para peserta.

3. Keberhasilan peserta dari hasil evaluasi sangat memadai yang ditandai dengan semua kegiatan dilakukan dengan tepat dan terarah. Walaupun demikian untuk evaluasi materi teori, peserta berada pada tingkatan normal. Ini disebabkan karena peserta terdiri dari unsur anggota kelompok tani yang usianya bervariasi.

\section{Saran}

Mengingat pelaksanaan kegiatan pelatihan ini sangat penting bagi masyarakat pada umumnya maka perlu dilaksanakan secara berkesinambungan. Pelaksanaan kegiatan ini sebaiknya tidak hanya dilakukan di salah satu kelompok kelompok saja yaitu kelompok tani nelayan Kamintong di Desa Eris Kecamatan Eris. tetapi di beberapa kelompok tani nelayan yang sejenis yang berada di seluruh Kabupaten Minahasa.

\section{KEPUSTAKAAN}

Al Haryono Jusup. 1999. Dasar-Dasar Akuntansi Jilid 1 Edisi 5. Yogyakarta: Bagian Penerbitan STIE YKPN.

Amin Wijaya Tunggal. 1997. Akuntansi Untuk Perusahaan Kecil dan Menengah, Jakarta: Rineka Cipta.

Anak Suryo, (2007). Akuntansi Untuk UKM, Metode akuntansi Praktis dan Sederhana untuk Usaha Kecil dan Menengah, Media Pressindo

Hery (2014). Akuntansi Untuk Pemula, Gava Media, Jakarta.

Mamik Krisdiartiwi, (2008). Pembukuan Sederhana Untuk UKM, Media Pressindo, Jakarta.

Mardiasmo. 2000. Akuntansi Keuangan Dasar Jilid 1 Edisi 3. Yogyakarta: BPFE UGM.

Mulyadi. 1993. Sistem Akuntansi Edisi 3. Yogyakarta: Bagian Penerbitan STIE YKPN. 
Jurnal ABDIMAS, Vol. 10, No. 2, Desember 2017

ISSN: 1979-0953

Mulyadi. 1993. Akuntansi Biaya Edisi 5.

Yogyakarta: Bagian Penerbitan STIE

YKPN. 